\title{
Attar and the West: The Role of Translation
}

\author{
Ailar Moghaddam Jahangiri \\ Fars Science and Research Branch, Islamic Azad University, Iran \\ Amin Karimnia \\ Fasa Branch, Islamic Azad University, Iran
}

\section{Introduction}

AbūHamīd bin AbūBakrIbrāhīmor Farid-uddin Attar Neishabouri or the Attar of Nishapur, was a Persian Muslim poet, a theoretician of Sufism and a hagiographer of the $6^{\text {th }}$ and the early $7^{\text {th }}$ century, who had an eternal influence on Persian poetry and Sufism (Kazemi, 2012). He was born in 530 (or likely) 537 A.H. in Kadkan, a village near Neishabour. Different authorities have determined various dates of his death, but the most reliable one according to his contemporaries - which was repeatedly mentioned in his poems - was in 627, i.e. he lived for around 90 years. Also, there is no exact evidence regarding the cause of his death and all the told stories were merely legends with no origin. His father also lived in Neishabour and was a chemist of his time. After his death, Attar continued his father's profession until the greatspiritual revolution occurred in his life and turned a new lease of life towards poetry and Sufism. There are different stories narrated by different authors about the spiritual revolution of Attar (Nafisi, 2003). This narration has been written by a French author, Louis Dubeux (1841), in a book named "La Perse". And, it seems that he has quoted this narration from the introduction of Silvestre de Sacy (1816) on Pandnamah of Attar:

A Dervish was gazing at the shop, his eyes filled with tears while letting out a sigh. "What are you staring at? It would have been wiser for you to continue going your own way" said the apothecary. "My load does not weigh much" he said. "I do not have much else but these old clothes, but what are you doing with these bags and barrels filledup with valuable medications? I can quickly leave this bazaar whenever I please, but you will be better if you plan and think of how you are going to collect your load.

This story is among the most deliberate and rational ones.

A large number of books have been attributed to Attar for authorship, but he had initially mentioned his main work in an introduction he had written in prose on 
Mukhtarnama and, lateron,in an introduction of Khosrownameh. The following nine books that he has mentioned definitely belong to him: Musibatnama, Ilahinama, Asrarnama, Mukhtarnama, Mantq Al-Tayr, Khosrownama, Javahernama, Sharh Al-Qalb, and Divan. He has other works such as Tadhkerat Al-Awlia, Pandnama, Pesarnama and etc. Despite the fact that he didn't name the mentioned books in his other compilers, they certainly belong to him (Nafisi, 2003).

\section{Translators}

Attar has received huge popularity among Western Orientalists as one of the most striking meteors in the Eastern sky of mysticism. Many of these Orientalists' works have been devoted to researching the works of Attar. From almost two hundred years ago, Europeans tried to introduce Attar's work to the West society (Fars News Agancy, 2012).

\section{Silvestre de Sacy}

Antoine Isaac Silvestre de Sacy was born on September 21, 1758and died on February 21, 1838 in Paris. He was a French linguist and Orientalist and a pioneer in modern Arabic studies (Answers, 2012). As far as Attar is concerned, de Sacy was one of the first European scholarsmost motivated in introducing Attar to the West.In 1816, Silvestre de Sacy translated the poems of Pandnama in Paris (Herman, 1977).

\section{John Haddon Hindley}

In other European countries, Pandnama introduced Attar's works to them. In 1819, Hindley, a Christian clergy, from Manchester University, published a great editorial review on Pandnama titled as "Pendeh-I-Attar" in London. In this review, the author put emphasis merely on the practical value of the content of Pandnama to help the colonial administrators to realize the Muslims' mindset (Keyvani, 2011).

\section{Gabriel GaiTelin}

The second translation of Pandnama was brought out in Latin by Gabriel GaiTelin in 1835 and published in Helinski, Finland (Keyvani, 2011). 


\section{Baron Eric Hermelin and Nestlman}

Baron Eric Hermelin was born in 1860 and died in 1944 in Sweden. He was known for his translations of Persian literature. He began his work by writing verses, annotations, and translations in local newspapers, having gradually adopted liberal attitude to have been soon attracted by mysticism. This attraction led him to translate classical Persian literature. In 1929 he translated Pandnama of Attar in Swedish. He has also translated Tadhkerat Al-Awlia in four volumes during the period of 1931-43. The impact of his translations was, however, limited due to his old-fashioned - andsometimes even strange and quirky style - inSwedish.His translations were so grandiose in $20^{\text {th }}$ century Swedish writing and Persian science (Wikipedia, 2012).

Yet other translations of Pandnama have been carried out by Nestlman (1871)in Germany. Moreover, there are several annotations and exegeses written on Pandnama which include: Shouri exegeses, Mostafa paraphrasal annotations known as Shamei, and Haj Mohammad Morad interpretation. Not only these, but also there are some other expositions written on Pandnama, for instance Pandnama interpretation in Urdu by Mowlana Sajjad Hossein(Sabzevari, pp. 766-767).

\section{The Impact of Pandnamathrough its Translations}

Attar has alwaysbeen put on a special pedestal in Turkish Literature and culture. Mehmet Akushin his speech - in Attar International Conference held in Neishabour- asserted that:"Intellectual products and works of Attar'shave had a profound influence on Turkish literature"; he went on to add: "This book had been taught as a textbook in theological seminary and in the schools of India \& Turkey" (Mehr News, 2012, Para.3).

\section{A.J. Arberry}

In 1966A.J. Arberry translated "Muslim Saints and Mystics", episodes from the Tadhkerat Al-Awliaby Farid al-Dtn 'Attar. Tadhkerat Al-Awliais a major work of Islamic mysticism. This thought-provoking and amusing selection, taken from Attar's Memorial of the Saints, is an enlightening introduction to the deeds, parables, and myriads of Muslim saints and mystics, and evokes the riches of the interior Sufi world. This book is onthe lives of reputableSufis and their miraculous deeds. It starts with a biography of ImamJafarSadiq, the Sixth Imam of Shia and ends with one of Mansur Al-Hallaj's, the Sufi Martyr (Arberry, 1966). Attar wrote 
96 Episodes in his book Tadhkerat Al-Awliaof which thirty-eight were translated by A. J. Arberry (1966). In an introduction of "Muslim Saints and Mystics", Attar lists his reasons for writing the book. R. A. Nicholson summarized his motives as follows:

1. He believed that the words of the saints were useful even to those who could not use them practically, inasmuch as they strengthen ambition and destroy selfadmiration.

2. The Koran and the Traditions cannot be understood without knowledge of Arabic, wherefore most people are unable to use them; and the Sayings of the Saints, which form a commentary on the Koran and the Traditions, were similarlystated, for the most part, in Arabic. Consequently, the author has translated them into Persian in order to be accessible to all.

3. He hoped that those who read the work would bless the author, and, thus, possibly, fortifies his prosperity beyond the grave... (Hafeez, 2012). Mehmet Akush also stated that Tadhkerat Al-Awlia has been published by six different publications in Latin alphabet (Mehr News, 2012).

\section{Edward Fitzgerald}

The Conference of the Birds (Mantq Al-Tayr) is the best-known work of Farid alDin 'Attar.In spite of its significance for world literature and the study of religion, Attar's poem was not translated entirelyuntil the mid-twentieth century, however, Edward Fitzgerald, best known as the translator of The Rubayyat of Omar Khayyam, worked on Mantq Al-Tayrand translated it under the title ofBird Parliament since 1857. He used free translation in his work(FitzGerald, 1889). As Davis (1984) stated, FitzGerald translates about a fifth of the poem, he rearranges the stories, sometimes bowdlerizes them and often translates very freely indeed (as he does in his versions of Khayyam). But, as with the Khayyam poems, he frequently succeeds in capturing much of the tone and feeling of the original.

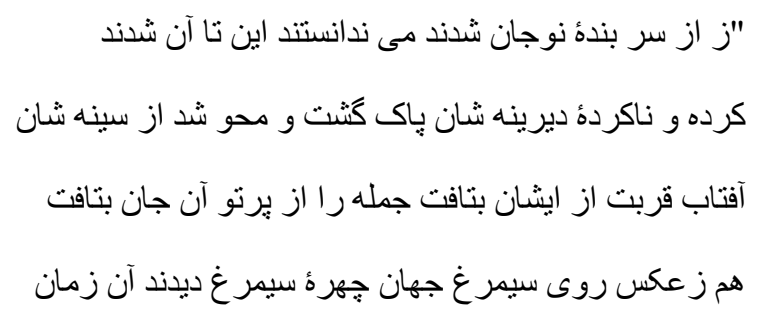




$$
\begin{aligned}
& \text { جون نحه كردند آن سى مرغ زود بـ شك اين سى مرغ آن سيمرغ بود } \\
& \text { در تحير جمله سركردان شدند اين ندانستند تا خود آن شدند } \\
& \text { خويش را ديدند سيمر غ تمام بود خود سيمر غسى مرغ تمام } \\
& \text { جون سوى سى مرغ كردند نحاه بود خود سيمرغ در آن جايگاه } \\
& \text { ور به سوى خويش كردندى نظر بود اين سى مرغ ايشان آن دكر } \\
& \text { ور نظر در هر دو كردندى به هم هر دو يك سيمرغ بودى بيش و كم } \\
& \text { بود اين يك، آن و آن يك، بود اين در همه عالم كسى نشنود اين } \\
& \text { آن همه غرق تحير ماندند بسى تفكر در تفكر مـاندند" } \\
& \text { (منطق الطير عطار، 1978: ص 214) }
\end{aligned}
$$

An example of Edward Fitzgerald's (1889) translation:

"And, their old selves self-knowledged and self-loathed,/And in the Soul's integrity re-clothed,

Once more they ventured from the Dust to raise/Their Eyes-up to the Throne-into the Blaze,

And in the Centre of the Glory there/Beheld the Figure of Themselves as'twere

Transfigured-looking to Themselves, beheld/The Figure on the Throne enmiracled,

Until their Eyes themselves and That between/Did hesitate which Seer was, which Seen;

They That, That They, Another, yet the Same;/Dividual, yet One: from whom there came

A Voice of awful Answer, scarecediscern'd/From which to Aspiration whose return'd

They scarcely knew; as when some Man apart/Answers aloud the Question in his Heart-

"The Sun of my perfection is a Glass/Wherein from seeing into Being pass

All who, reflecting as reflected see/Themselves in Me, and Me in Them: not Me,

But all of Me that a contracted Eye/Is comprehensive of Infinity:/Nor yet Themselves: no Selves, but of The All 
Fractions, from which they split and whither fall/.Come you lost Atoms to your Centre draw,

And be the Eternal Mirror that you saw:/Rays that have wander'd into Darkness wide

Return, and back into your Sun subside.”

\section{Dick Davis \& Afham Darbandi}

In 1984, Dick Davis \& Afham Darbandi translated Mantq Al-Tayr under the title of "The Conference of the Birds". It contains many anecdotes about Sufis who suffered for their beliefs. Translating the aesthetic rhythmic narration of Mantq-Al Tayr (The Conference of the Birds) they embarked upon making good application of the Mozdavaj-e-Hamasi (epic doublet) which bears great resemblance to Masnavi moulding (Tavalaei, 2001).

Davis\& Darbandi (1984) stated:

The way of the Sufi is expounded here in tales that are often riddling and sometimes obscure, but full of incident and suspense, laced with quick character sketches and witty vignettes of everyday life in twelfth-century Persia. Above all, though, the puts into words themes of love and the search for divine unity; in conveying these Attar 'has transformed belief into poetry, much in the same way that Milton or Dante did'.(Back cover, The Conference of the Birds, Davis \& Darbandi 1984, para.2)

In the body of the poem itself, species of the birds of the world gather together to decide who is to be their king, as they had already had none. The hoopoe, the wisest of them all, suggests that they should find the legendary Simorgh, a mythical Persian bird roughly equivalent to the Western Phoenix. The hoopoe leads the birds in their quest; each of the accompanying birds represents a certain human fault which prevents man from attaining enlightenment. The birds have to cross seven valleys in order to find the Simorgh: Talab (Search), Eshq (Love), Marifat (mystic Apprehension), Istighnah (Detachment), Tawheed (Unity of God), Hayrat (Bewilderment) and, finally, Fuqur and Fana (Fulfilment in Annihilation). Once the group of the thirty birds finally reaches the dwelling place of the Simorgh, all they find is a lake in which they see their own reflection (Darbandi\& Davis, 1984).

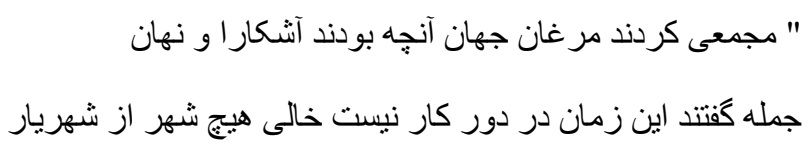




$$
\begin{aligned}
& \text { جون بود كاقليم ما را شاه نيست بيش از اين بـ شاه بودن ر اه نيست } \\
& \text { يك دكر را شايد ار بارى كنيم بِادشاهى را طلب كارى كنيم } \\
& \text { زانكه جون كثور بود بـى يادشاه نظم و ترتيبى نماند در سيّاه } \\
& \text { بس همه با جايعاهى آددند سر به سر جوياى شاهى آددند" } \\
& \text { (منطق الطير . مجمع مر غان44-2010) }
\end{aligned}
$$

A sample of Darbandi\& Davis (1984)translation:

"The world's birds gathered for their conference

And said: "Our constitution makes no sense.

All nations in the world require a king;

How is it we alone have no such thing?

Only a kingdom can be justly run;

We need a king and must inquire for one."

$$
\begin{aligned}
& \text { "ابتداى كار سيمرغ ای عجب جلوه كر بكذشت بر جين نيم شب } \\
& \text { در ميان جين فتاد از وى يرى لاجرم يُرشور شد هر كثورى } \\
& \text { (منطق الطير. حكايت سيمرغ46-2010) }
\end{aligned}
$$

"It was in China, late one moonless night,

The Simorgh first appeared to mortal sight --

He let a feather float down through the air,

And rumours of its fame spread everywhere;"

\section{Anne Fairbairn}

TheConference of the Birds has proven to have the capacity to spark the imaginations of writers, poets, musicians and directors throughout the English-speaking world. Anne Fairbairn, the Australian poet, recast Attar's masterpiece in a contemporary Australian context to grant it some more understandable backdrop in her book named "An Australian Conference of the Birds" in 1995. Having 
compiled this book, she has produced a masterpiece of poetry in Australian English (Newman, 2009).

The versification of Attar's original by Anne Fairbairn does not lose its inspirational touch from Mantq-Al Tayr. Fairbairn has only managed to pick the original framework of Attar's poesy; she has not gone for the subsidiary anecdotes thereof. The lack of such style of narration causes Fairbairn's poetry - on the one hand - to get fully shipshaped into the English language to be only based on the Pantheistic motif, and - on the other - to not have the tendency to get as close as Attar's to the justified expression of Mysticism. Her turn of language is anecdotal and secretive as is that of Attar's (Tavalaei, 2001). The versified story in the blank format does contain rhythmical couplets, although without rhymes, which actually makes it more familiarly similar to the everyday spoken English.

Anne Fairbairn in her Australian Conference of the Birds has intentionally brought out the original into English so that she might expose the chaotic situation in her own contemporary era and society. As mentioned, she does not possess the depth of insight of Attar's (Gerdfaramarzi, 1993).

$$
\begin{aligned}
& \text { "مرحبا اى هدهد هادى شده در حققت بِيك هر و ادى شده } \\
& \text { اى به سر حد سبا سبر نو خوش با سليمان منطق الطير تو خوش } \\
& \text { صاحب سير سليمان آمدى از تفاخر تاجورزان آمدى } \\
& \text { ديو را در بندو زندان بازدار تا سليمان را تو بانشى رازدار } \\
& \text { ديو را وقتى كه در زندان كنى با سليمان قصد شادروان كنى" } \\
& \text { (منطق الطير. آغاز كتاب. 41-2010) - (مئ) }
\end{aligned}
$$

An example of Anne Fairbairn (1995) translation:

"'O Hoopoe Bird, you call me down the years, you who have passed across an abyss of fears by a bridge much finer than a human hair, beset by terror. As you say, only those birds who peck away their souls to know the highest love, can find Tariqat.

Help us, O Hoopoe, for on your beak is etched 
the blessed word Bismillah for all to see.

King Solomon could speak in your warbling tones;

you understood each other, heart to heart

so you carried messages from his court

to Belquis, Sheba's Queen. For your valour

he honoured you with a golden feathered crest."

\section{Special Focus: Translations of Helmut Ritter}

The mystic literature has - for the most part of its chronology - being akin to much quirky play on secrets of Sufism so much so that any full comprehension of concepts, allegories, phraseology, incidental idealization and knowledge of symbols thereof has never turned out to be a facile routine. There is absolutely no doubt that the plane working on different degrees of "Mysticism" has differed among various writers and poets of mystic thought in classical Persian literature. As far and as long as Attar is concerned, his style of writing and poetizing seems to be less arduous as compared with other significant authorities on either Sufism or Mysticism. This is despite the fact that Attar has not made specific attempts to reduce the high - level Persian Mysticism into popular pap for the common layman on the street: he has just not made any effort to overly complicate basic ideas of Mysticism with abundant use of abstruse language. This is not just claimed by the present paper, but mostly recognized to be so by the majority of experts (Iranian and otherwise) on classical Persian Mystic writings (Ritter, 1995).

There have been a relatively large number of researchers on Attar of whom possibly one of the most important is Helmut Ritter. Helmut Ritter, one of Germany's greatest Orientalists, is an inspiring model of scholarship for anyone professionally active in the field of Islamic studies. His work under the German title of "Das Meer Der Seele" [Mensch, Welt und Gottin Den Geschichten Attar] (The Ocean of the Soul: Mankind, World, and God in the works of Attar) delves deep into the idiosyncrasy of Attar in the 6th century A.H. Mysticism.Helmut Ritter managed to spend much time, energy, and research project on Attar to try to put to the best use his unfathomable knowledge of Latin, Persian, Greek, and Arabic to turn Attar from Farsi into German. It was in 1940 when he edited the second work of Attar's, i.e. "Ilahinama". Later, in 1955, he produced his masterpiece on Attar's brand of mysticism over four prominent works of: "Mantq Al-Tayr", "Ilahinama", "Asrarnama", and "Musibatnama" under the title of "Das 
Meer Der Seele". There is little doubt that "Das Meer Der Seele" has been the outcome of years upon years of the professor's investigation and research.

These four Masnavi contains common themes in religious and mystics and each emblazoned with small anecdotes. Almost half a century having passed, "Das Meer Der Seele" has been able to keep its position as the most significant study on Attar's works and ideas. Many more printing has been done on the book since its first appearance in 1955. "Das Meer Der Seele" has proven to be the gateway to understanding how Attar has been able to almost completely infiltrate into a western professor of Oriental literature (Kane, 2003, ZaryabKhoei \& Baybordi, 1995). As an example of John O'kane's translation from the German version of Helmut Ritter of "The Ocean of the Soul":

"To be sure, fear (khawf) of eternal punishment, of being predestined for damnation, is not by any means eliminated but it does find a counterbalance in hope (raja) in God's mercy. Alongside God's harsh violence (qahr, jalal) stands his kindness, grace and mercy (lutf, jamal, inayat, rahmat), alongside his threat (wa id) there is His promise (wa d) and, according to the divine saying, God's mercy has precedence over His wrath."

(The Ocean of the Soul: 264, 1955)

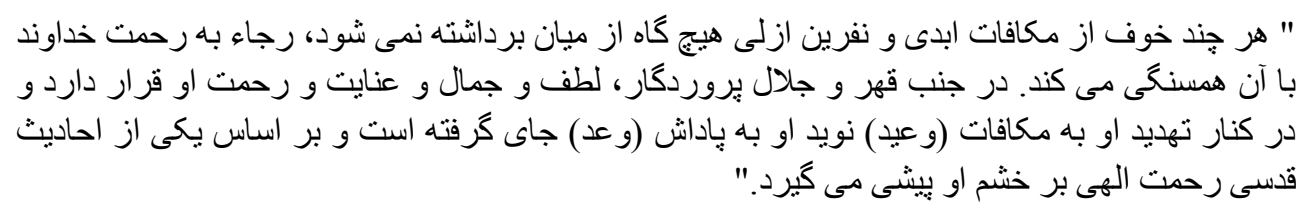

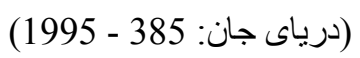

We could hardly hesitate to assert that Helmut Ritter is on the same level of receiving impression from Attar as Nicolson has received his own impression from Mowlana. Nay, Ritter has - through long years of being read and reviewed maintained his position as the most profound exegesis on Attar, though he might not have been well known throughout the world, sometimes even in academic circles. Quoting at length from 'Attar and other Islamic sources, Ritter sketches an extraordinarily vivid portrait of the Islamic attitude toward life, characteristic developments in pious and ascetic circles, and, in conclusion, various dominant mystical currents of thought and feeling. Special attention is given to a wide range of views on love, love in all its manifestations, including homosexuality and the commonplace Sufi adoration of good-looking youths. Ritter's approach is throughout based on precise philological interpretation of primary sources, several of which he has himself made available in critical editions. Helmutt Ritter himself 
says: "I know one thing full well, and it is that I can penetrate into others' characters deeply". Helmutt Ritter's prominent student Fritz Mayer who comes from Switzerland says: "Ritter has been able to dip deep into his subjects of interest. He did not see these various topics from the viewpoint of a European. Ritter has also had the capacity to find the relationships between Attar and other Sufis like Imam Mohammad Ghazali and Ahmad Ghazali. He, moreover, found the original verses of Koran where hidden references had been made by Attar to: without openly and vividly mentioning by chapter and verse those specific verses of the holy book of Islam that has given rise to a large number of hemistiches in various lines of the huge compilations of Attar's. As an example, when Ritter came to the part of Mantiq- Al Tayr where the different species of birds came over to Simorgh in order to ask after their companion travelers who had happen to lose their lives on the way, the answer as coming from the Simorgh to the various species of birds was traced by Ritter to go back to (Surah 2/154) translated as "do not believe that who were killed on the path of God are death" (Zaryab Khoei\& Baybordi, 1995).

\section{Editorial Reviews}

Many translations, editions and reviews have been performed alongside the main translations done on Attar's work. John O'kane (1963) professor in Classics, Princeton University, is an independent scholar who translated "The Ocean of the Soul" of Helmut Ritter with some editorial assistance of Bernd Radtke. His translations include The Secrets of God's Mystical Oneness (Mazda, 1992), Fritz Meier, Essays on Islamic Piety and Mysticism (Brill, 1999) and The Feats of the Knowers of God (Manāqeb al-'ārefin) by Shams al-Din Aḥmad-eAflākī (Brill, 2002). The articles presented in the Nov. 2002 conference on Attar in Britain were, later, to be put into the format of a more comprehensive book under the editing superintendence of two illustrious Orientalists named Leonard Lewisohn and Christopher Shackle by the subtitle of "The Art of Spiritual Flight" and under the title of "Attar and the Iranian Tradition of Sufism".

\section{Conclusion \& Discussion}

Attar had a great influence on a wide range of those scholars and translators who are interested not only in Mysticism, but also in comparative theology throughout the world. Attar's methodology is not that unfamiliar to the readership acquainted with medieval European literature; indeed, Attar's poems are so close in tone and 
technique to medieval European classics that a large number of Western critics have gone to the point of using words such as "empathy" or "telepathy" when coming to comparing and collating occidental/Oriental Mystic writings before the onset of Renascence. To western readers, Attar's fallacies about other religions may sometimes prove annoying at least to some part of His audience; still his characterizations of monasteries as places where orgies go on and good Moslems are led astray is after all no more bizarre than medieval Christian characterizations of what went on in Jewish communities. The interactions between the different poles of Ibrahamic religions have not failed to contrast themselves both in works of literature and in writings of purely theological nature. Attar's language is, compared with many Persian poets, fairly direct and does not show too many obstaclesfor the translator (Davis \&Darbandi, 1984).

The very convention of the international conference on Attar Neishabouri is due to the significance of his poems and works around the world. In Nov. 2002, the international conference on Attar was held in London and brought together scholars from around the world. This conference aims not only to celebrate the marvelous beauty of Attar's verse, prose and to make a comprehensive study of his literary works, but to investigate his Mystical doctrine, by situating his poetry and prose within the wider context of the Persian Sufi tradition. There has not been a point in the history of Persian literature that has not received at least a shade of Attar's way of thinking in formulating Sufi ideology after Attar himself. Shackle, (SOAS, University of London), gave a presentation in an international conference held in London on the special literary style and the significance of anecdote in Mantq Al-Tayr of Attar and also Attar's Tale of Shaykh San'an and the Christian Girl in 2002. In this conference, Lewis, professor of Persian language at the University of Georgia, collated the Semiotics of Feminine Virtue in Chaucer (1965) and Attardespite his comparative research. Having mentioned the Ilahinama anecdote of Attar, he came to the conclusion that Shaykh Attar demonstrates a good figure of a feminine virtue in Ilahinama which is quite dissimilar from that of other feminine images in Persian poetry. J.C.Bürgel, (Bern University, Switzerland), propounded the special attention of Shaykh Attar and his taking advantage of Quran and Hadith in: Ilahinama, Mantq Al-Tayr, Oshtornama and Musibatnama in an article titled as "Repetitive Structures in the Epic Poetry of Attar and their Functions".

Bürgel stated, by mentioning the tale of Joseph and Zoleika, that Attar has been more successful in depicting this story of Quran than that of other Persian poets (Iran Heritage Founfation, 2002). 
As another instance of Attar's influence on Western groups of arts \& literature, although this time amongst the modern, present-day Westerners, the musical group "Om" recorded an album called "Conference of the Birds"in 2006; moreover, the director Peter Brook, along with Jean-Claude Carriere, adapted The Conference of the Birdsfor the stage in a version that was published in 1982. As for the prospect of such an endeavor, the British poet Ted Hughes prepared one hundred poems with rhythmical motifs rooted in the poetry attributed to Attar. (Newman, 2009).

Attar's works had also a great impress on Helmut Ritter. Ritter found the depth of Quranic verses and their interpretations through hemistiches originally having their roots in Koran (ZaryabKhoei \& Baybordi, 1995). Attar's penetration in the West is observable through the translations and books written upon his opinions and ideas. Before the research of the Iranians to identify Attar Neishabouri, Western orientalists had begun their own investigating 200 years ago. Approximately two centuries ago, Europeans were planning to educate the population about Attar Neishabouri's findings. Although French translators are among the first who introduced Attar to the Western society, the most significant work in this field was done by the British and the Germans (Tebyan, 2008).

\section{References}

Answers. (2012). Retrieved December 24, 2012, from http://www.answers.com.

Arberry, A. J. (1966). Muslim Saints and Mystics. London and Boston: Routledge and Kegan Paul.

Baybordi, A. Z. (1395). Daryaye Jan. Tehran: Alhoda International Publications.

Davis, D.\& Darbandi, A. (1984). The Conference of the Births. London: Penguin .

Fars News Agancy. (2012, dec 22). Retrieved December 24, 2012, from http://www.farsnews.com.

FitzGerald, E. (1889). Bird Parliament. London and New York: Macmillan and Co.

Gerdfaramarzi, A. (1993). Simorgh dar ghalamro farhang Iran. Tehran: Mobtakeran.

Hafeez, M. A. (2012, december 23). yanabi. Retrieved December 24, 2012, from http://www.yanabi.com.

Herman, E. (1977). History of Persian Literature. Tehran: Bongah Tarjome va Nashre Ketab.

Iran Heritage Founfation. (2002). Retrieved December 24, 2012, from http://www.iranheritage.org.

Kane, J. O. (2003). The Ocean of the Soul. Bonn: Brill.

Kazemi, A. M. (2012, april 18). press TV. Retrieved December 24, 2012, from http://edition.presstv.ir/detail/236902.html.

Keyvani, M. (2011, july 7). Shahre Ketab database. Retrieved December 24, 2012, from http://www.bookcity.org.

Mehr News. (2012, December 23). Retrieved December 24, 2012, from http://www.mehrnews.com. 
Nafisi, s. (2003). The biography of Shaykh Farid-uddin Attar Neishabouri, Tehran: Eghbal.

Newman, R. J. (2009, December 13). Translating Classical Iranian Poetry: Farid al-Din Attar. Retrieved January 08, 2013 from http://www.richardjnewman.com.

Ritter, H. (1995). The Ocean of the Soul/Daryaye Jan. Tehran: Alhoda International Publications.

Sabzevari, R. M. (n.d.). Pandama Attar. Tehran: Islamic Culture and Relations Organization.

Tebyan. (2008, April 15). Retrieved from December 24, 2012, http://www.tebyan.net.

Tavalaei, M. (2001). From phoenix to an Australian conference of the birds . Journal of The Faculty of Literature \& Humanities .

Wikipedia. (2012, November 18). Retrieved January 05, 2013, from http://en.wikipedia.org.

\section{Appendix A: List of Translations of Attar's works in Chronological Order:}

\begin{tabular}{|l|l|l|l|l||}
\hline & Translator & Translations & To & Date \\
\hline 1 & Silvestre de Sacy & Poem of Pandnama & French & 1816 \\
\hline 2 & G. H. Hindeli & $\begin{array}{l}\text { Editorial Review on } \\
\text { Pandnama }\end{array}$ & English & 1819 \\
\hline 3 & Gabriel GaiTelin & Pandnama & Latin & 1835 \\
\hline 4 & Edward Fitzgerald & Bird's Parliament & English & 1857 \\
\hline 5 & Nestlman & Pandnama & German & 1871 \\
\hline 6 & Baron Eric Hermelin & Pandnama & Swedish & 1929 \\
\hline 7 & Baron Eric Hermelin & Tadhkerat Al-Awlia & Swedish & $1931-43$ \\
\hline 8 & Helmut Ritter & Edition of Ilahinama & German & 1940 \\
\hline 9 & Helmut Ritter & Das Meer Der Seele & German & 1955 \\
\hline 10 & A.J. Arberry & $\begin{array}{l}\text { Muslim Saints and Mystics } \\
\text { episodes from the Tadhkerat } \\
\text { Al-Awlia }\end{array}$ & English & 1966 \\
\hline 11 & $\begin{array}{l}\text { Dick Davis } \\
\text { \&AfhamDarbandi }\end{array}$ & The Conference of the Birds & English & 1984 \\
\hline 12 & Anne Fairbairn & $\begin{array}{l}\text { An Australian Conference of } \\
\text { the Birds }\end{array}$ & Australian & 1995 \\
\hline
\end{tabular}




\title{
Summary
}

\section{Attar and the West: The Role of Translation}

\author{
Ailar Moghaddam Jahangiri \\ Science and Research Branch, Islamic Azad University, Iran
}

\section{Amin Karimnia}

Fars Science and Research Branch, Islamic Azad University, Iran

The present study investigated the influence of Attar Neishabouri, the $6^{\text {th }}$ and the early $7^{\text {th }}$ century Persian poet and the theoretician of Sufism, through translations done in the West. Here, the main works of Attar have been introduced and the available translations done of his work have been reviewed. "The Conference of the Birds", "The Ocean of the Soul", "The Muslim Saints and Mystics" and "The Birds' Parliament"are among the translations done of his works. Although, French translators are among the first who introduced Attar to the Western society, the most important work in this field was done by the British and the Germans. Among them is Helmut Ritter, the German Orientalist, who created the most prominent translation done on Attar's works.

Key Words: Attar Neishabouri, Translations, the Conference of the Birds, the Ocean of the Soul, the Muslim Saints and Mystics, the Birds' Parliament 